Prepared in cooperation with the Lansing Board of Water and Light

\title{
Delineation of Contributing Areas to Selected Wells in Ingham County, Michigan
}

Open-File Report 2014-1054 



\section{Delineation of Contributing Areas to Selected Wells in Ingham County, Michigan}

By Carol L. Luukkonen

Prepared in cooperation with the Lansing Board of Water and Light

Open-File Report 2014-1054 


\title{
U.S. Department of the Interior SALLY JEWELL, Secretary
}

\section{U.S. Geological Survey Suzette M. Kimball, Acting Director}

\author{
U.S. Geological Survey, Reston, Virginia: 2014
}

For more information on the USGS - the Federal source for science about the Earth, its natural and living resources, natural hazards, and the environment, visit http://www.usgs.gov or call 1-888-ASK-USGS.

For an overview of USGS information products, including maps, imagery, and publications, visit http://www.usgs.gov/pubprod

To order this and other USGS information products, visit http://store.usgs.gov

Any use of trade, firm, or product names is for descriptive purposes only and does not imply endorsement by the U.S. Government.

Although this information product, for the most part, is in the public domain, it also may contain copyrighted materials as noted in the text. Permission to reproduce copyrighted items must be secured from the copyright owner.

Suggested citation:

Luukkonen, C.L., 2014, Delineation of contributing areas to selected wells in Ingham County, Michigan:

U.S. Geological Survey Open-File Report 2014-1054, 11 p., http://dx.doi.org/10.3133/ofr20141054

ISSN 2331-1258 (online) 


\section{Contents}

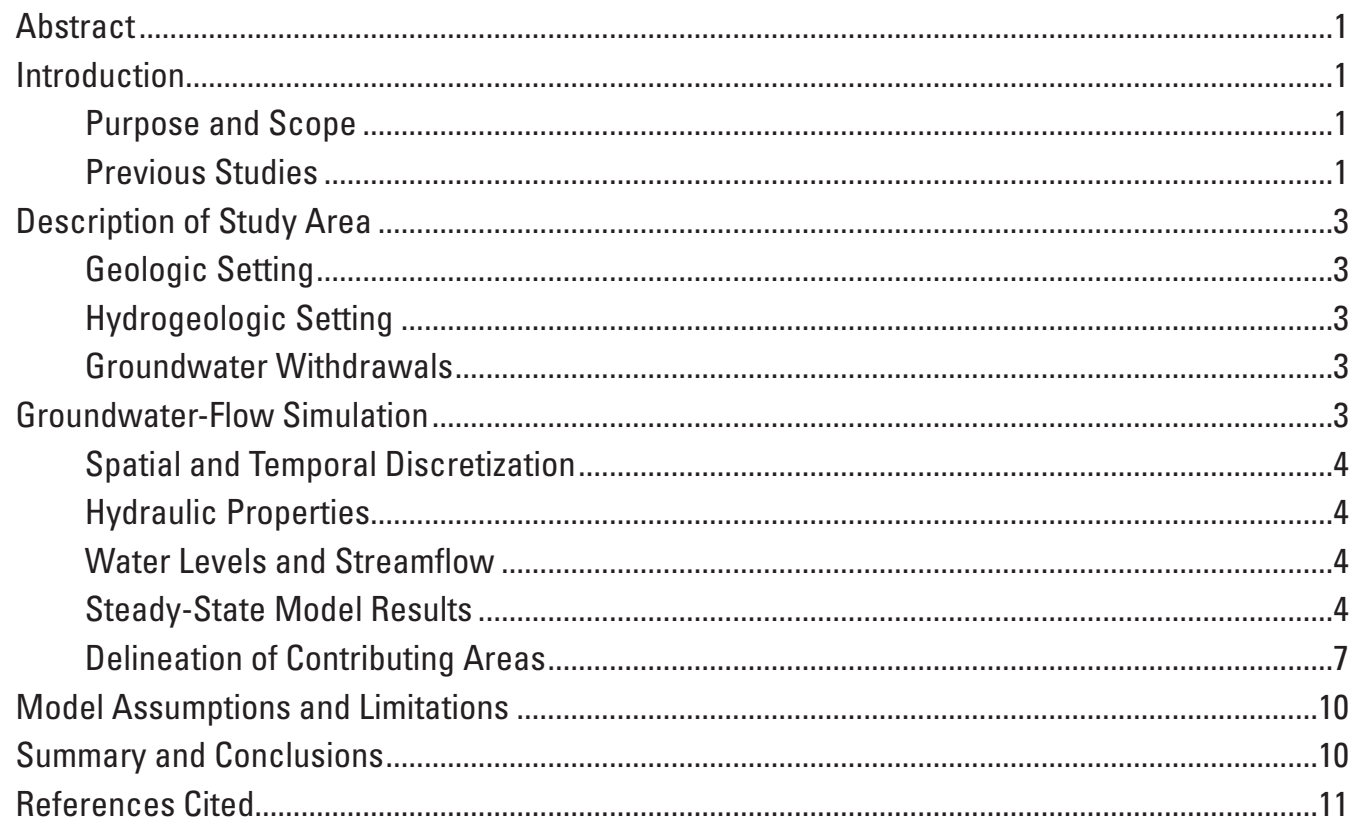

\section{Figures}

1. Location of the Tri-County regional model area, participating communities, and the nine-township area surrounding Lansing, Michigan .

2. Summary of model budget for 2011-12 pumping conditions, Tri-County region, Michigan ......................................................................................

3. Relation between observed and simulated water levels and streamflow, Tri-County model, Michigan.

4. Simulated 10-year time-of-travel areas for selected production wells in the nine-township area, Tri-County region, Michigan ............................................................

5. Simulated 40-year time-of-travel areas for selected production wells in the nine-township area, Tri-County region, Michigan

\section{Tables}

1. Base-flow estimates at eight U.S. Geological Survey (USGS) streamgaging stations in the Tri-County region 


\section{Conversion Factors and Datums}

\begin{tabular}{|c|c|c|}
\hline Multiply & By & To obtain \\
\hline \multicolumn{3}{|c|}{ Length } \\
\hline foot $(\mathrm{ft})$ & 0.3048 & meter $(\mathrm{m})$ \\
\hline mile (mi) & 1.609 & kilometer (km) \\
\hline \multicolumn{3}{|c|}{ Area } \\
\hline square foot $\left(\mathrm{ft}^{2}\right)$ & 929.0 & square centimeter $\left(\mathrm{cm}^{2}\right)$ \\
\hline square foot $\left(\mathrm{ft}^{2}\right)$ & 0.09290 & square meter $\left(\mathrm{m}^{2}\right)$ \\
\hline square mile $\left(\mathrm{mi}^{2}\right)$ & 2.590 & square kilometer $\left(\mathrm{km}^{2}\right)$ \\
\hline \multicolumn{3}{|c|}{ Volume } \\
\hline gallon (gal) & 3.785 & liter (L) \\
\hline gallon (gal) & 0.003785 & cubic meter $\left(\mathrm{m}^{3}\right)$ \\
\hline million gallons (Mgal) & 3,785 & cubic meter $\left(\mathrm{m}^{3}\right)$ \\
\hline cubic foot $\left(\mathrm{ft}^{3}\right)$ & 28.32 & cubic decimeter $\left(\mathrm{dm}^{3}\right)$ \\
\hline cubic foot $\left(\mathrm{ft}^{3}\right)$ & 0.02832 & cubic meter $\left(\mathrm{m}^{3}\right)$ \\
\hline \multicolumn{3}{|c|}{ Flow and recharge rate } \\
\hline foot per day (ft/d) & 0.3048 & meter per day $(\mathrm{m} / \mathrm{d})$ \\
\hline cubic foot per second $\left(\mathrm{ft}^{3} / \mathrm{s}\right)$ & 0.02832 & cubic meter per second $\left(\mathrm{m}^{3} / \mathrm{s}\right)$ \\
\hline gallon per day (gal/d) & 0.003785 & cubic meter per day $\left(\mathrm{m}^{3} / \mathrm{d}\right)$ \\
\hline million gallons per day (Mgal/d) & 0.04381 & cubic meter per second $\left(\mathrm{m}^{3} / \mathrm{s}\right)$ \\
\hline inch per year (in/yr) & 25.4 & millimeter per year (mm/yr) \\
\hline \multicolumn{3}{|c|}{ Hydraulic conductivity } \\
\hline foot per day (ft/d) & 0.3048 & meter per day $(\mathrm{m} / \mathrm{d})$ \\
\hline
\end{tabular}

Vertical coordinate information is referenced to the North American Vertical Datum of 1929 (NVGD 29).

Horizontal coordinate information is referenced to the Michigan State Plane Coordinate System, South Zone.

Altitude, as used in this report, refers to distance above the vertical datum. 


\title{
Delineation of Contributing Areas to Selected Wells in Ingham County, Michigan
}

\author{
By Carol L. Luukkonen
}

\section{Abstract}

A groundwater-flow model that was constructed in 2009 was updated to reflect recent (2011-12) pumping conditions in the Tri-County region, which consists of Clinton, Eaton, and Ingham Counties, Michigan. As part of local wellhead protection area programs, areas contributing water to local production wells must be periodically updated, because groundwaterflow paths depend in part on the stresses, such as groundwater withdrawals, to the groundwater-flow system. For this current (2013) study, withdrawals from selected city of Lansing production wells were updated, and simulated heads and flows under the new pumping conditions compared favorably to previously measured values. Results of flow simulations indicate that 10-year time-of-travel contributing areas cover approximately 19.4 square miles, and 40-year time-of-travel contributing areas cover approximately 39 square miles.

\section{Introduction}

The Tri-County region, which consists of Clinton, Eaton, and Ingham Counties, covers 1,697 square miles $\left(\mathrm{mi}^{2}\right)$ in the south-central part of the Lower Peninsula of Michigan (fig. 1). A groundwater-flow model developed in 1996 (Holtschlag and others, 1996) was refined in 2009 (Luukkonen, 2009) in cooperation with the Tri-County Regional Planning Commission and local communities in order to better represent the groundwater flow system in the Tri-County region. Participating communities included Alaiedon Township, Bath Township, Delhi Township, Delta Township, city of East Lansing, city of Eaton Rapids, city of Lansing, city of Williamston, Eaton Rapids Township, Lansing Township, Michigan State University, Meridian Township, Oneida Township, Vermontville Township, Village of Dimondale, Watertown Township, Williamstown Township, and Windsor Township. The 2009 study helped to improve understanding of the regional hydrologic system in the Lansing area, and the groundwater-flow model continues to be used for planning and protection of the water supplies in the Lansing area. As part of local wellhead protection area programs, areas contributing water to local production wells need to be periodically updated, because groundwater-flow paths depend in part on the stresses to the groundwater-flow system. Different pumping rates or pumping locations will change the groundwater-flow patterns in the modeled area and result in different zones of contribution and areas contributing recharge to the pumping wells; therefore, for this current (2013) study, prepared in cooperation with the Lansing Board of Water and Light, withdrawals from selected production wells were updated to reflect 2011-12 pumping conditions, simulated heads and flows under the new pumping conditions were compared to previously measured values, in part to ensure boundary conditions of the original model were still appropriate, and contributing areas to production wells were delineated.

\section{Purpose and Scope}

This report briefly describes the 2009 Tri-County regional groundwater-flow model and the simulation of 2011-12 pumping conditions. Simulated water levels and streamflow under the new pumping conditions were compared to observed water levels and streamflow used in the 2009 model and a new set of water levels and flow from more recent measurements from 2006-9. These updated pumping conditions were used with particle-tracking analysis to determine 10- and 40-year timeof-travel contributing areas to selected production wells. The limitations of the model for assessing groundwater levels and flow and for delineating contributing areas are described.

\section{Previous Studies}

Several previous studies contributed to the development of the 2009 model. A report by Holtschlag and others (1996) documents how the 1996 regional groundwater-flow model was developed and used to determine contributing areas for most production wells in the Tri-County region. Two reports describe refinement of the grid spacing of the original 1996 model and the results of additional groundwater-flow simulations in the north Lansing area (Luukkonen and others, 1997a, b). Finally, a report by Luukkonen (2009) describes additional refinements to the 1996 model and subsequent simulations investigating the groundwater flow system in the Tri-County area. 


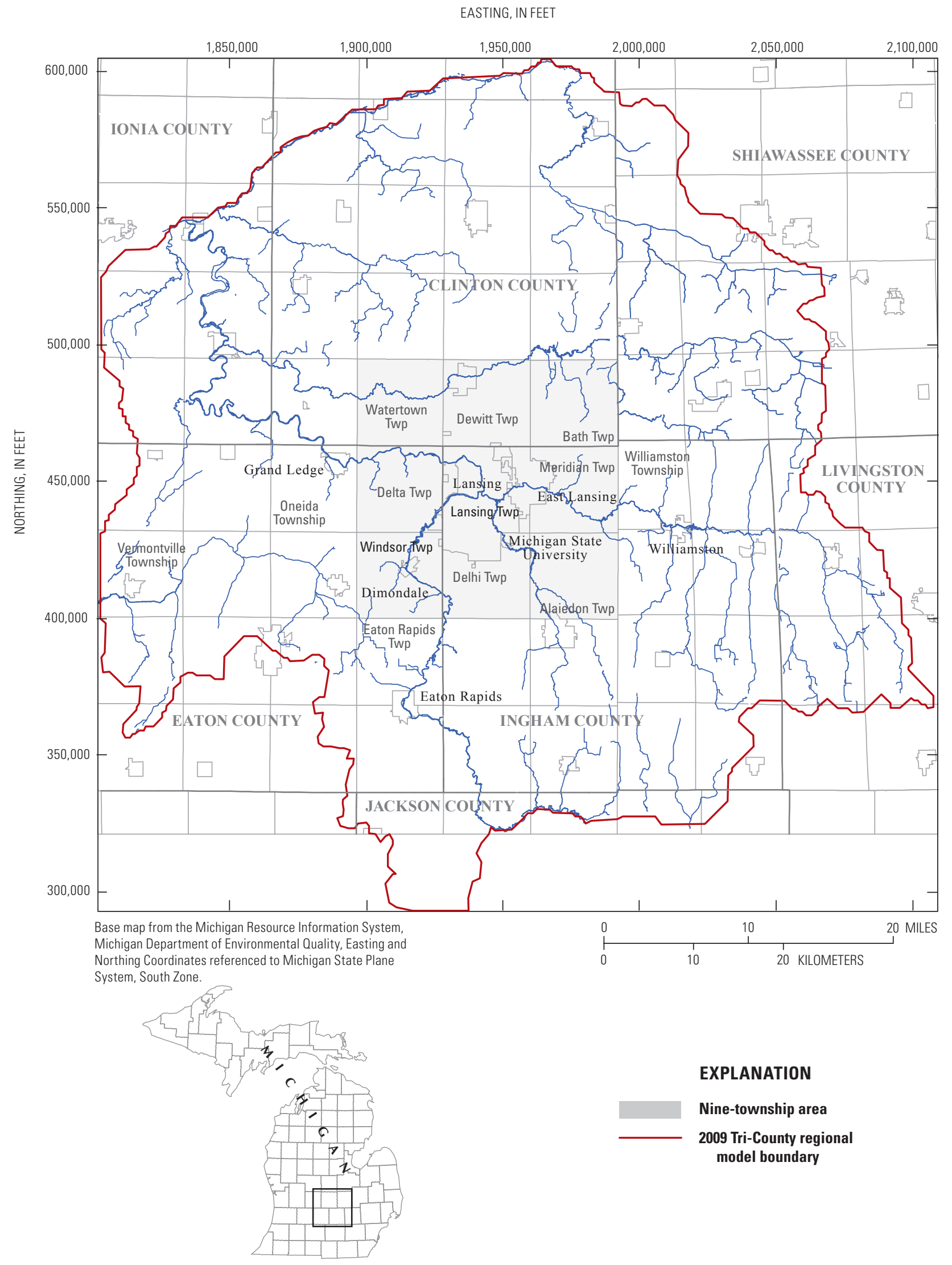

Figure 1. Location of the Tri-County regional model area, participating communities, and the nine-township area surrounding Lansing, Michigan. 


\section{Description of Study Area}

In this report, the "nine-township area," which is in and surrounding the city of Lansing, Michigan, consists of Alaiedon, Bath, Delhi, Delta, Dewitt, Lansing, Meridian, Watertown, and Windsor Townships (fig. 1). The nine-township area is the principal area of municipal groundwater withdrawals in the Tri-County region. Groundwater is withdrawn primarily from the Saginaw aquifer, which consists of water-bearing sandstones within the Grand River and Saginaw Formations of Pennsylvanian age. Aquifers in the glacial deposits and other bedrock units are important groundwater sources in some places. The primary geologic, hydrogeologic, and water-use characteristics that affect groundwater flow in the Saginaw aquifer are described in the following sections. More detailed information is available in Luukkonen (2009).

\section{Geologic Setting}

In the Tri-County region, Pennsylvanian rocks form the uppermost bedrock unit. The Pennsylvanian rocks are thickest in the west-central part of Clinton County and generally thin to the south. They are absent in the extreme eastern part of Ingham County. Discontinuous lenses of sandstone, shale, coal, and limestone in the Pennsylvanian bedrock units have been formally subdivided into two formations. The uppermost Grand River Formation consists of massive, coarse-grained sandstones; all remaining Pennsylvanian rocks are considered part of the underlying Saginaw Formation (Mandle and Westjohn, 1989). The assignment of formation is not precise, however, because no lithologic differences or stratigraphic horizons mark a change from one formation to the next (Westjohn and Weaver, 1996). Jurassic red beds separating Pennsylvanian rocks from overlying glacial deposits in some areas of the Lower Peninsula are either entirely absent or only marginally present in the TriCounty region (Westjohn and others, 1994). For the purposes of this study, all deposits between the top of the Pennsylvanian rocks and the land surface were assumed to be glacial deposits.

The glacial features in Michigan are the result of ice advances during late Wisconsin time $(35,000$ to 10,000 years before present). The glacial deposits are absent in a small area near the city of Grand Ledge; the thickest glacial deposits are in the northwestern part of the study area. These deposits are generally not regionally continuous; hydrogeologic properties vary across the study area (Mandle and Westjohn, 1989).

\section{Hydrogeologic Setting}

Glacial deposits form the uppermost aquifer in the TriCounty region. Groundwater flow in the glacial deposits is generally from south to north, away from topographic divides and toward surface-water bodies. Aquifers in the glacial deposits are composed primarily of coarse alluvial and outwash materials. Till is present over much of the region and is generally not a source of water to wells (Vanlier and others, 1973).
The Saginaw aquifer is in water-bearing sandstones in the Grand River and Saginaw Formations. The Saginaw aquifer can be thought of as an aquifer system consisting of three sandstone units separated by an upper interbedded-series unit and a lower shale unit (David Westjohn, U.S. Geological Survey, oral commun., 2005). Division of the Saginaw aquifer into these units is uncertain in some areas because of incomplete or missing well-log data, heterogeneities within the units, and varying thicknesses of these units in the formation. Most groundwater flow in the Saginaw aquifer is from south to north, although some is toward local pumping centers. Flow between aquifers in the glacial deposits and the Saginaw Formation is limited where confining units are present that consist of: (1) a lower till unit in the glacial deposits, (2) an upper shale unit in the Saginaw Formation, or (3) both types of confining units.

\section{Groundwater Withdrawals}

Groundwater is the principal source of water supply for the Tri-County region and the majority of communities rely on groundwater from the Saginaw aquifer; in 2010 about 95 percent of municipal withdrawals were from the Saginaw aquifer (Andy LeBaron, 2012, Michigan Department of Environmental Quality, written commun.). Domestic, agricultural, and industrial supplies may be from the Saginaw aquifer or glacial deposits. Groundwater withdrawals in the 2009 model totaled $45.3 \mathrm{Mgal} / \mathrm{d}$ (million gallons per day) and represented 2006-7 conditions. For this study, simulated groundwater withdrawals for 88 Lansing production wells in the central part of the model area were updated to reflect 2011-12 pumping conditions (Bill Maier, 2013, Lansing Board of Water and Light, written commun.), with about equal numbers of wells with increasing and decreasing pumping rates; other municipal withdrawals were unchanged from the 2009 model. Groundwater withdrawals totaled $46.1 \mathrm{Mgal} / \mathrm{d}$ in the updated steady-state model. Pumpage generally increased for wells in the western and northern parts of the wellfield and decreased for wells in the southeastern part.

\section{Groundwater-Flow Simulation}

The U.S. Geological Survey modular three-dimensional finite-difference numerical groundwater-flow model MODFLOW-2000 (Harbaugh and others, 2000) was used to simulate groundwater flow in the Tri-County region. The steady-state model area consists of Clinton, Eaton, and Ingham Counties along with parts of Ionia, Shiawassee, Jackson, and Livingston Counties (fig. 1). Simulated pumping rates for 88 city of Lansing wells were updated to reflect more recent conditions; all other model values and boundary conditions were not changed for the current study. A brief description of the model, hydraulic characteristics, and water-level and streamflow data and the comparison between model simulated and observed water levels and flow are described below. For a more detailed description of the model construction see Luukkonen (2009). 


\section{Spatial and Temporal Discretization}

The model area covers about $3,500 \mathrm{mi}^{2}$ and is approximately 61 miles (mi) long (north-south) and $58 \mathrm{mi}$ wide (east-west). The model consists of 338 rows and 307 columns of grid cells that vary in size. In the central part of the model area, each cell is approximately 660 by 660 feet (ft). Cell spacing increases outward from the central part of the model area in each direction by a factor of 1.2 to a maximum grid spacing of about $1,330 \mathrm{ft}$.

Three units were determined to represent the glacial materials. The uppermost glacial unit (layer 1) was thickest for deposits adjacent to rivers to minimize problems associated with model convergence of calculated water levels. The remaining glacial materials were subdivided equally to create layers 2 and 3.

The Saginaw Formation materials were divided into an uppermost shale unit overlying three aquifer units that are separated by an interbedded-series confining unit consisting of shale and sandstone lenses and a lowermost shale unit. The uppermost shale confining unit (layer 4) is thickest in Clinton County and the northern part of Eaton County. The shale unit is absent in parts of Lansing and is thinnest over most of southern Ingham and Eaton Counties. The uppermost sandstone aquifer unit (layer 5) is thickest in the central Tri-County region and northern Clinton County. The interbedded-series confining unit (layer 6) is thickest in the eastern, western, and northern parts of the Tri-County region. The intermediate sandstone aquifer unit (layer 7) is thickest in central and northern parts of the Tri-County region. The lower shale confining unit (layer 8) is thickest in the central and northern parts of the Tri-County region. The lowermost sandstone aquifer unit (layer 9) is thickest in Ingham and Eaton Counties. The lowermost model layer (layer 10) represents the material underlying the Saginaw aquifer and was included because well logs indicate that some wells may be completed below the bottom of the Saginaw aquifer.

\section{Hydraulic Properties}

Estimates of hydraulic conductivity ranged from 12.7 to 107.2 feet per day (ft/d) for the glacial aquifer units (model layers 1, 2, and 3). Horizontal hydraulic conductivity estimates are highest in the central and eastern parts of the model area and lowest in the northern and southern parts of the model area. Vertical hydraulic conductivity estimates ranged from 0.0001 to $0.027 \mathrm{ft} / \mathrm{d}$.

The estimated horizontal hydraulic conductivities for the shale (layer 4) are highest in the southern model area and lowest in the central and northeastern model area and ranged from 0.0004 to $0.435 \mathrm{ft} / \mathrm{d}$. The estimated horizontal hydraulic conductivity of the sandstone (layers 5, 7, and 9) equaled $11 \mathrm{ft} / \mathrm{d}$, and the vertical hydraulic conductivity estimate equaled $1.1 \mathrm{ft} / \mathrm{d}$. The sandstone transmissivity estimates vary according to the sandstone thickness and are highest in the central and northern model area and lowest in the southern model area. Horizontal hydraulic conductivity estimates for the interbedded series (layer 6) and the lower shale (layer 8) equaled $0.1 \mathrm{ft} / \mathrm{d}$ and $0.01 \mathrm{ft} / \mathrm{d}$, respectively. The horizontal hydraulic conductivity for the bottom bedrock unit was estimated to be a constant value of $8 \mathrm{ft} / \mathrm{d}$, and the vertical hydraulic conductivity was estimated to be 0.1 times the horizontal value, or $0.8 \mathrm{ft} / \mathrm{d}$. Streambed hydraulic conductivity was estimated to be $4.6 \mathrm{ft} / \mathrm{d}$.

\section{Water Levels and Streamflow}

Simulation results with the updated pumping rates were compared to water-level and streamflow data used for calibration of the 2009 model and to more recent water-level and stream flow data. Within the Tri-County region, water-level data used for calibration of the 2009 model consisted of 2,775 water-level measurements from well logs (Holtschlag and others, 1996). Measurements in the upper layer were not restricted to a particular time period; however, measurements in the lower layer were restricted to the period 1984-92 because of local trends in the historical groundwater-level data associated with changes in pumping conditions. Streamflow data used for calibration of the 2009 model consisted of base-flow estimates at 10 continuous-record streamgaging stations and 25 partial-record streamgaging stations. Daily mean streamflows from streamgaging stations were disaggregated into surface runoff and base flow components by use of a streamflow partitioning technique (Rutledge, 1993). The average base flow component was assumed to represent the average groundwater discharge. Some more recent water-level data are available from well logs from the Michigan Department of Environmental Quality Wellogic database (Michigan Department of Environmental Quality, 2013). These additional water level and streamflow data representing more recent conditions (2000-9) were compiled as an additional check on model results. These water-level data consisted of 2,284 water-level measurements obtained from well logs for wells installed from 2005-9 in the glacial deposits and 2006-9 in the Saginaw aquifer; streamflow data (table 1) consisted of baseflow estimates at 8 continuous-record streamgaging stations determined using flows from 2000-5.

\section{Steady-State Model Results}

In the steady-state model, the amount of water recharging the ground-water system is assumed to equal the amount of water discharging from the ground-water system; changes in storage do not occur. Water may enter the system as recharge from precipitation, seepage from lakes and rivers, and as inflow from outside the study area. Water may leave the ground-waterflow system as seepage into lakes and rivers, outflow from the study area, and as withdrawals by wells. The model budget indicates that the majority of flow out of the model is to rivers and the majority of inflow is from recharge (fig. 2). 
Table 1. Base-flow estimates at eight U.S. Geological Survey (USGS) streamgaging stations in the Tri-County region.

[Streamflow data from 2000-5 were used to estimate base flow by use of a streamflow partitioning technique (Rutledge, 1993)]

\begin{tabular}{clclc}
\hline $\begin{array}{c}\text { USGS gaging- } \\
\text { station number }\end{array}$ & \multicolumn{1}{c}{ Station name } & Drainage area & \multicolumn{1}{c}{ Period of record } & $\begin{array}{c}\text { Base flow(cubic feet } \\
\text { per seond) }\end{array}$ \\
\hline 04111379 & Red Cedar River near Williamston & 163 & $1975-89,2001-13$ & 75.1 \\
04111500 & Deer Creek near Dansville & 16.3 & $1954-2013$ & 7.2 \\
04112000 & Sloan Creek near Williamston & 9.34 & $1954-2013$ & 2.7 \\
04112500 & Red Cedar River at East Lansing & 355 & $1903,1931-2013$ & 152.2 \\
04113000 & Grand River at Lansing & 1,230 & $1901-6,1934-2013$ & 664.5 \\
04114000 & Grand River at Portland & 1385 & $1952-82,1988-2013$ & 786.7 \\
04114498 & Looking Glass River near Eagle & 280 & $1944-96,2001-13$ & 131.0 \\
04111000 & Grand River at Eaton Rapids & 661 & $1950-82,1995-2013$ & 430.2 \\
\hline
\end{tabular}

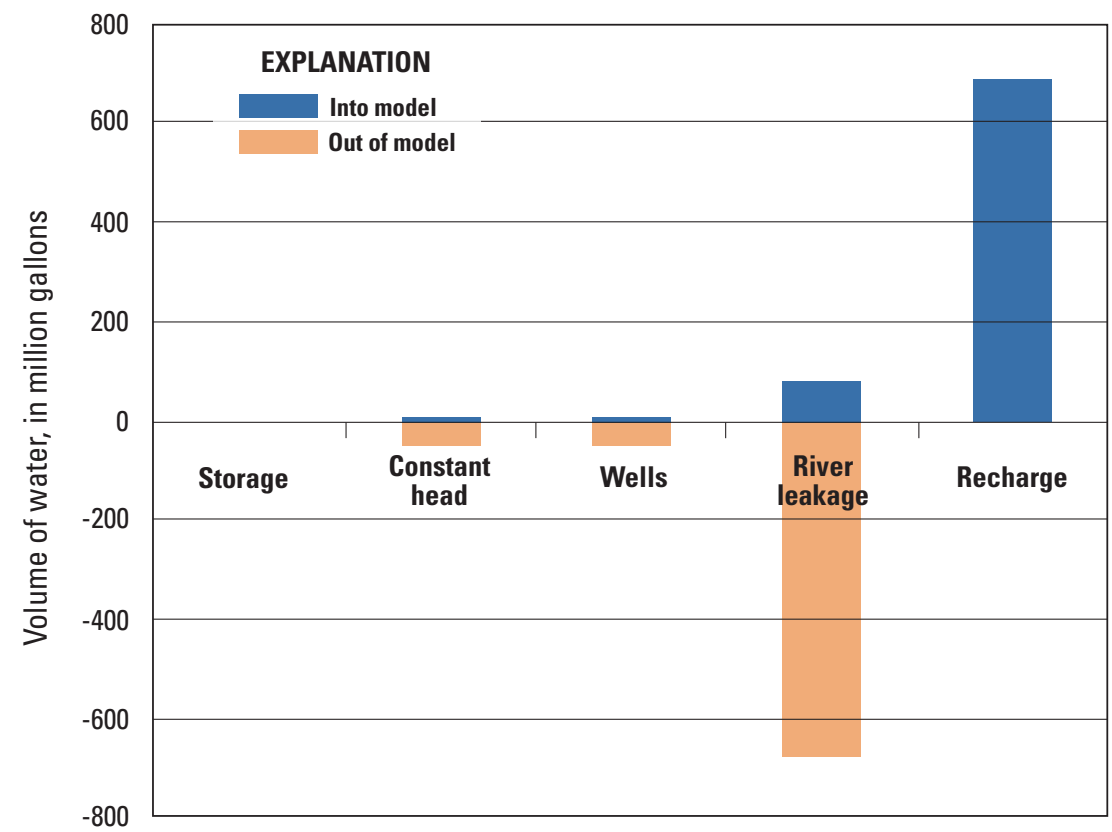

Figure 2. Summary of model budget for 2011-12 pumping conditions, Tri-County region, Michigan 
Model fit is evaluated by comparing the magnitude and distribution of the differences (residuals) between observed and simulated water levels and flows. Simulated water levels and flows can be plotted against observed values, and the deviation from the 1:1 line gives one indication of model fit. Simulation results for the refined 2009 10-layer model using
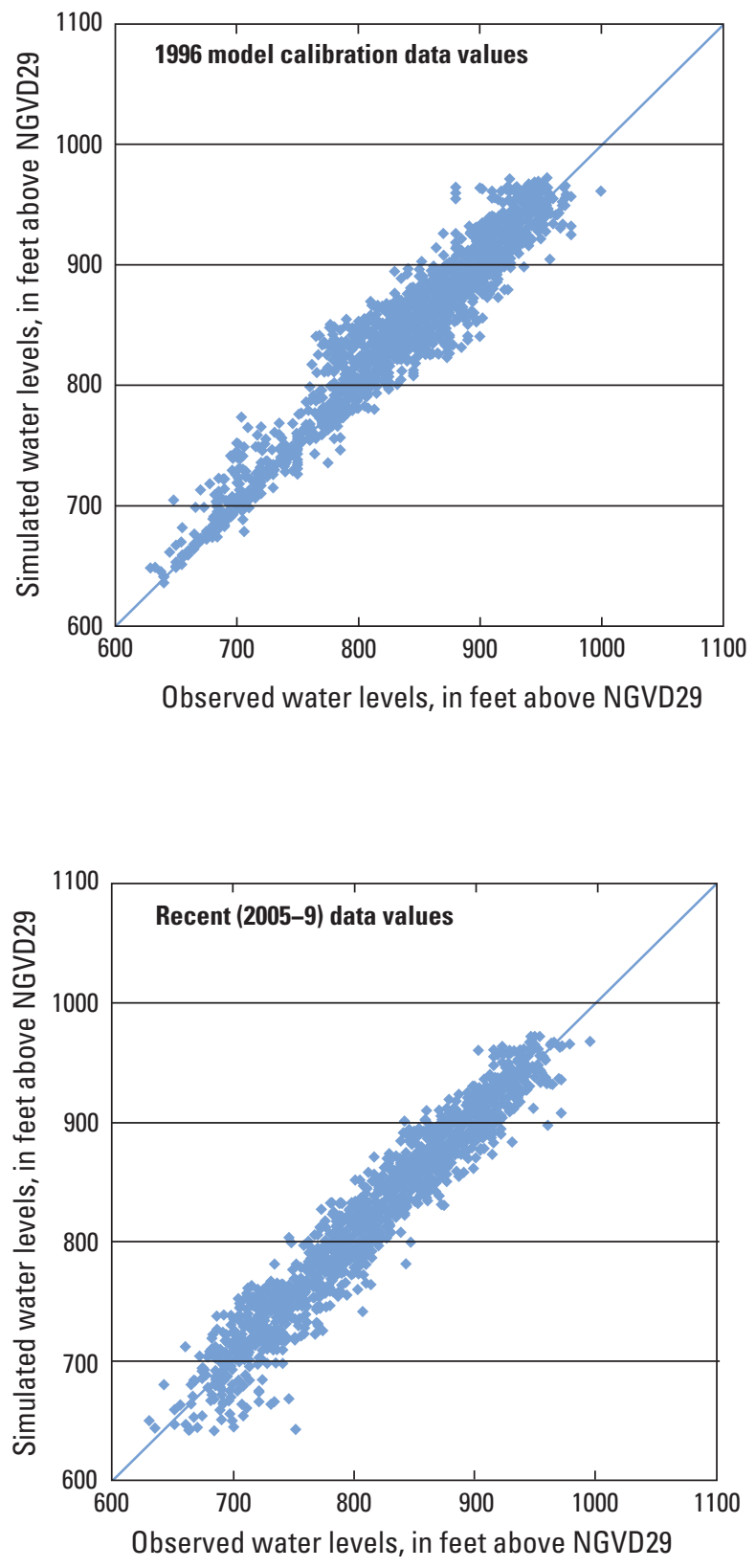

2011-12 pumping conditions were compared to observations used in the development of the 1996 model and to a second set of water-level and streamflow observations from 2000-9. The agreement between observed and simulated groundwater levels and streamflow was similar for both sets of calibration data (fig. 3).
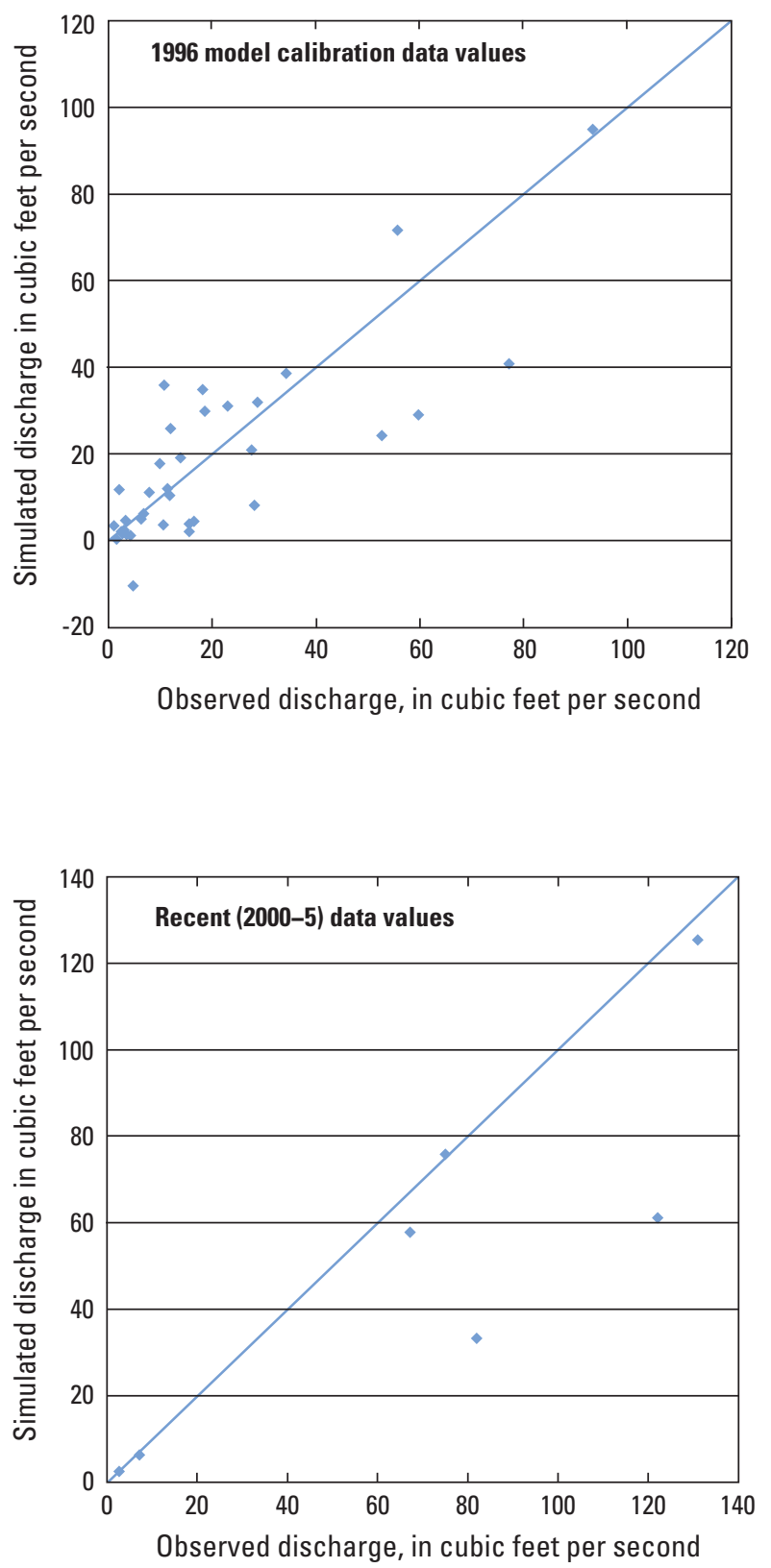

Figure 3. Relation between observed and simulated water levels and streamflow, Tri-County model, Michigan, (NGVD 29, National Geodetic Vertical Survey Datum of 1929).. 
As described in Holtschlag and others (1996), observation weights were based on the assumed accuracy in the measurement. Measurements from the Wellogic database were estimated to be accurate within $\pm 7 \mathrm{ft}, 90$ percent of the time. Measurements at monitoring wells were estimated to be accurate within $\pm 2 \mathrm{ft}, 90$ percent of the time. Using the water levels and streamflow from the 2009 study, the sum of squared weighted residuals (SSWR) for heads decreased from 16,170 in the 1996 model to 10,452 in the 2009 model and equaled 10,387 in the 2009 model with 2011-12 pumping conditions; the mean water-level residual is $4.6 \mathrm{ft}$. The SSWR for streamflow measurements increased slightly from 350 in the 1996 model to 415 in the 2009 model and equaled 391 under the new pumping scenario. This comparison indicates that (1) the model conceptualization and boundary conditions are still appropriate with the updated pumping conditions, and (2) the differences between observed and simulated water levels and flows are not great enough to require recalibration of the model before estimating contributing areas.

\section{Delineation of Contributing Areas}

The particle-tracking program MODPATH (Pollock, 1994) can be combined with MODFLOW-calculated flow in each cell to determine the zone of contribution to a pumping well within a given time frame. The zone of contribution to a pumping well is defined as the land-surface projection of the three-dimensional volume of water flowing to the pumping well (Morrissey, 1989). That three-dimensional volume includes the surficial contributing recharge area and any subsurface zones of contribution. The contributing area for each pumping well is defined here as the combination of areal extent of the areas contributing recharge and of the zones of contribution projected up to the land surface. An estimated porosity of 15 percent was previously used for particletracking simulations (Holtschlag and others, 1996) and, in the absence of any additional information, was used for all layers in the 2009 model.

A total of 24,000 hypothetical particles were placed on the sides of the cells in the Saginaw aquifer layers containing the 88 Lansing-area production wells with updated pumping rates. These particles were tracked backward using the steadystate model along flow paths through the groundwater-flow field until they reached a top cell face (representing the land surface) in the upper model layer or until a specified amount of time elapsed. Consequently, the position of the particle at the end of the simulation represents the location at the water table where the particle enters (recharges) the groundwaterflow system or the location where water would flow to the well in the specified amount of time. Groundwater withdrawals of 46.1 Mgal/d representing 2011-12 conditions were specified for this simulation. Surface areas contributing recharge as well as subsurface zones of contribution were determined for 10 and 40 years using the 2009 model with the modified withdrawals. Under 2011-12 pumping conditions, the areal extent of the 10-year time-of-travel wellhead-contributing areas encompasses about $19.4 \mathrm{mi}^{2}$ (fig. 4); the areal extent of the 10 -year time-of-travel areas under 2007 pumping conditions encompassed about $19.2 \mathrm{mi}^{2}$. Contributing areas were generally larger in the western and northern parts of the wellfield and smaller along the eastern side of the wellfield. The areal extent of the 40-year time-of-travel areas encompasses about $39 \mathrm{mi}^{2}$ under 2011-12 pumping conditions (fig. 5). 
EASTING, IN FEET

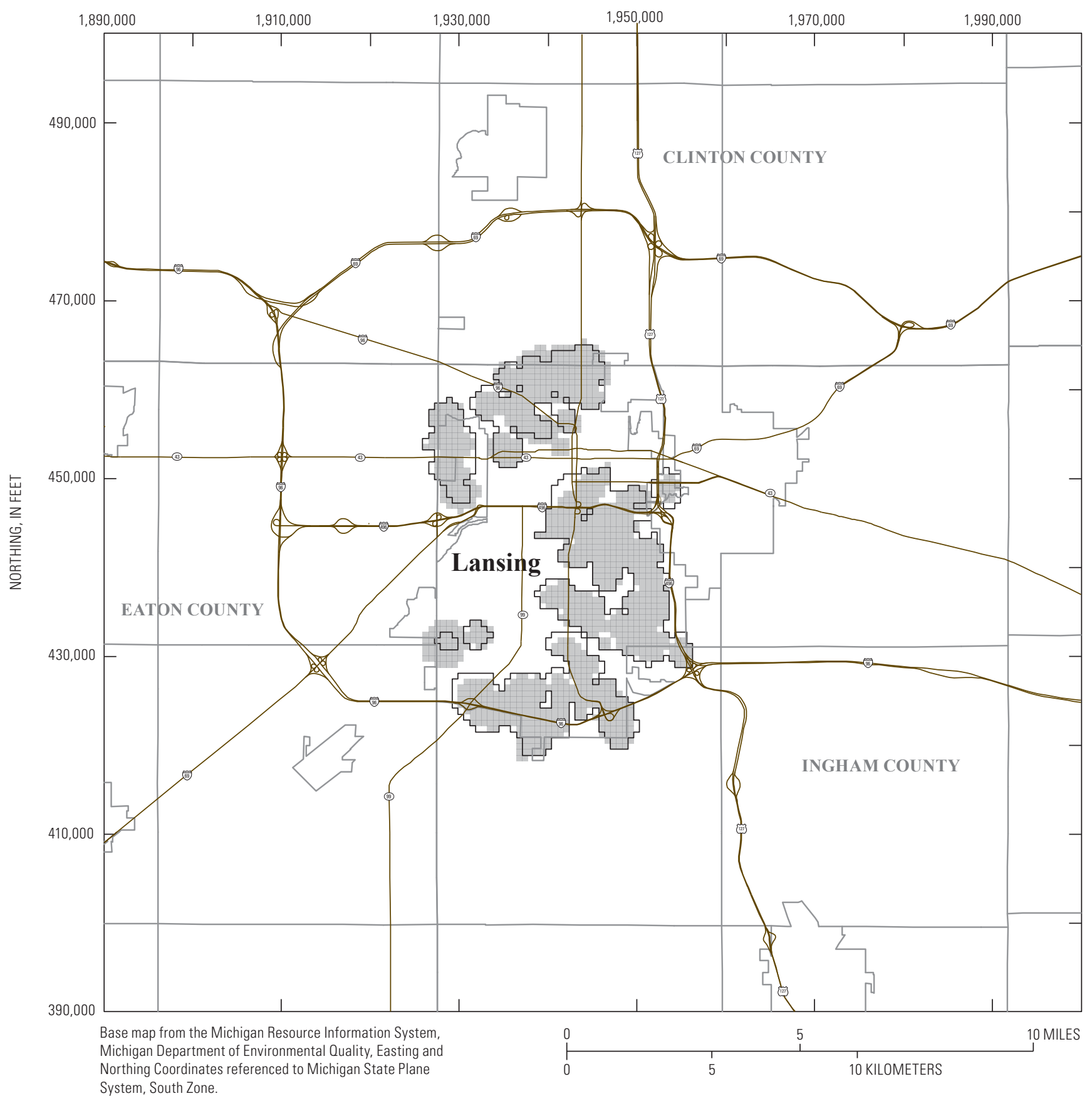

\section{EXPLANATION}

10-year time of travel areas under 2011-12 pumping conditions

10-year time of travel areas under 2007 pumping conditions

Figure 4. Simulated 10-year time-of-travel areas for selected production wells in the nine-township area, Tri-County region, Michigan. 


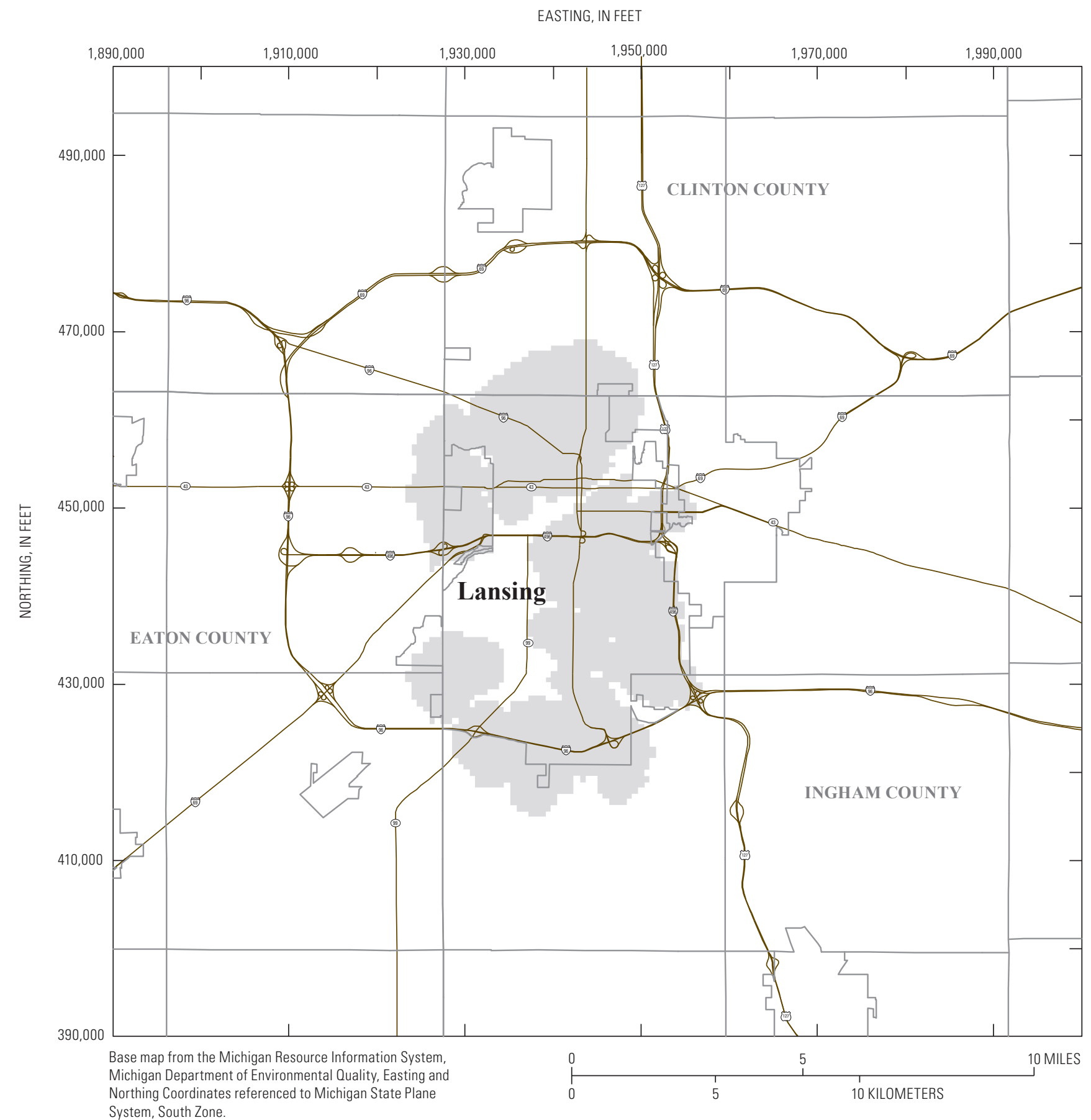

EXPLANATION

Simulated 40-year time of travel areas for selected production wells

Figure 5. Simulated 40-year time-of-travel areas for selected production wells in the nine-township area, Tri-County region, Michigan. 


\section{Model Assumptions and Limitations}

The groundwater-flow model was developed to simulate the regional groundwater-flow system in the Tri-County region. Hydraulic properties represented in each layer were assumed to be horizontally isotropic; that is, within a cell, hydraulic properties are the same in the north-south direction as in the east-west direction. Hydraulic properties do vary from location to location; however, each grid cell represents the average hydraulic properties in the volume of aquifer represented by the cell. Vertical variations in aquifer properties within layers and any variations in head or flow within each layer are not simulated in the model. Local flows over distances smaller than the dimensions of the grid cell also cannot be accurately simulated. Additional geologic and hydrologic data, as well as finer discretization of the model, would be needed to simulate flow systems in smaller areas. The accuracy of layer surfaces and hydraulic conductivity estimates are limited by the available data at well and boring locations. Additional control and accuracy could be achieved by inclusion of more data points.

Small withdrawals from domestic wells were not included because of the difficulty in obtaining reliable data and the limitations in representing small-scale flow systems (systems considerably smaller than simulated as part of this study). However, domestic groundwater withdrawals and the unaccounted-for effects are probably small at the scale of the model.

The base of the model is assumed to be impermeable. External boundary conditions, which are based on natural hydrologic conditions and are distant from the Tri-County region well fields, are assumed to have minimal effect on water levels and flow in the interior of the model. The model may not accurately represent the groundwater-flow system for any predictive simulations involving groundwater withdrawals near the model boundaries.

The location and size of the areas contributing recharge to wells are affected by the hydrogeologic characteristics and boundary conditions of the groundwater-flow system, as well as the location, depth, and discharge rate of each simulated well. Thus, the simulated areal extent of the areas contributing recharge and zones of contribution are dependent on the estimated values for the hydraulic characteristics, such as transmissivity and riverbed conductance, and on the pumping rates of the individual wells. In reality, the size and location of the zone of contribution could change over time as a function of annual or seasonal variations in pumping rates or pumping locations. In addition, the zone of contribution could change in size or location with changes in recharge rates or in the way the groundwater-flow system is represented.

The accuracy of particle-tracking simulations is limited by the accuracy of the numerical model on which the simulations are based, the estimates of the effective porosity of the flow system, and the accuracy of the cell flow velocities in approximating the local groundwater-flow velocities. Actual effective porosity may differ from location to location and from layer to layer. Lower effective porosities in the system would tend to increase the rate that particles move and increase the size of the contributing areas to the wells. Particle tracking simulates the advective movement of groundwater, so the effects of diffusion, dispersion, and chemical reactions are not considered. Therefore, particle tracking, by itself, is not sufficient for simulating all aspects of the transport of dissolved chemicals in the groundwater-flow system. Under steady-state conditions, the water discharging from a pumped well is a blend of water of different ages or traveltimes. In each specified time-of-travel simulation, it is assumed that model pumping rates and pumping locations remain constant indefinitely and that the water withdrawn by each simulated well may represent water that has entered as recharge or that already was in the zone of contribution when the well began pumping. Simulations of transient processes (with changes in recharge and/or pumping) may affect the size and shape of the areas contributing recharge (Reilly and Pollock, 1996).

\section{Summary and Conclusions}

A groundwater-flow model that was constructed in 2009 was updated to reflect recent (2011-12) pumping conditions in the Tri-County region, which consists of Clinton, Eaton, and Ingham Counties, Michigan. The Saginaw aquifer, which consists of water-bearing sandstones in the Grand River and Saginaw Formations of Pennsylvanian age, is the primary source of groundwater for Tri-County residents. As part of local wellhead protection area programs, areas contributing water to local production wells need to be periodically updated because groundwater-flow paths depend in part on the stresses to the groundwater-flow system. Different pumping rates or pumping locations will change the groundwater-flow patterns in the modeled area and result in different zones of contribution and areas contributing recharge to the pumping wells. Therefore, for this current (2013) study, withdrawals from selected production wells were updated to reflect 2011-12 pumping conditions, simulated heads and flows under the new pumping conditions were compared to measured values, and contributing areas to production wells were delineated.

Contributing areas to wells (defined for this study as the combination of the areal extent of the areas contributing recharge and of the zones of contribution projected up to the land surface) were delineated for selected Tri-County region production wells by using particle-tracking analysis. Groundwater withdrawals for 2011-12 totaled 46.1 Mgal/d. Results of flow simulations indicate that 10 -year time-of-travel areas cover approximately $19.4 \mathrm{mi}^{2}$, and 40-year time-of-travel areas cover approximately $39 \mathrm{mi}^{2}$. 


\section{References Cited}

Harbaugh, A.W., Banta, E. R., Hill, M.C., and McDonald, M.G., 2000, MODFLOW-2000, the U.S. Geological Survey modular ground-water model-User guide to modularization concepts and the ground-water flow process: U.S. Geological Survey Open-File Report 00-92, 121 p.

Holtschlag, D.J., 1994, A generalized estimate of groundwater recharge rates in the lower peninsula of Michigan: U.S. Geological Survey Water-Supply Paper 2437, 81 p.

Holtschlag, D.J., Luukkonen, C.L., and Nicholas, J.R., 1996, Simulation of ground-water flow in the Saginaw aquifer, Clinton, Eaton, and Ingham Counties, Michigan: U.S. Geological Survey Water-Supply Paper 2480, 49 p.

Luukkonen, C.L., 2009, Model refinement and simulation of groundwater flow in Clinton, Eaton, and Ingham Counties, Michigan: U.S. Geological Survey Scientific Investigations Report 2009-5244, 53 p.

Luukkonen, C.L., Grannemann, N.G., and Holtschlag, D.J., 1997a, Ground-water flow in the Saginaw aquifer in the vicinity of the north Lansing well field, Lansing, Michigan-Part 1, Simulations with a regional model: U.S. Geological Survey Open-File Report 97-569, 13 p.

Luukkonen, C.L., Grannemann, N.G., and Holtschlag, D.J., 1997b, Ground-water flow in the Saginaw aquifer in the vicinity of the north Lansing well field, Lansing, Michigan-Part 2, Simulations with a regional model using a reduced cell size: U.S. Geological Survey Open-File Report 97-570, $25 \mathrm{p}$.

Mandle, R.J., and Westjohn, D.B., 1989, Geohydrologic framework and groundwater flow in the Michigan basin, in Swain, L.A., and Johnson, A.I., eds., Regional aquifer systems of the United States, Aquifers of the Midwestern area: 24th Annual Conference of American Water Resources Assoc., Milwaukee, Wis., 1988, AWRA Monograph Series 13, p. 83-109.
Michigan Department of Environmental Quality, Wellogic Database, 2013: accessed February 6, 2013 at https://www. michigan.gov/deq/0,4561,7-135-6132_6828-16124-,00. html.

Morrissey, D.J., 1989, Estimation of the recharge area contributing water to a pumped well in a glacial drift, river-valley aquifer: U.S. Geological Survey Water-Supply Paper 2338, $41 \mathrm{p}$.

Pollock, D.W., 1994, User's guide for MODPATH/MODPATH-PLOT, Version 3: A particle tracking post-processing package for MODFLOW, the U.S. Geological Survey finite-difference ground-water flow model: U.S. Geological Survey Open-File Report 94-464, 6 ch.

Reilly, T.E., and Pollock, D.W., 1996, Sources of water to wells for transient cyclic systems: Groundwater, v. 34, no. 9, p. 979-988.

Rutledge, A.T., 1993, Computer programs for describing the recession of ground-water discharge and for estimating mean ground-water recharge and discharge from streamflow records: U.S. Geological Survey Water-Resources Investigations Report 93-4121, 45 p.

Vanlier, K.E., Wood, W.W., and Brunett, J.O., 1973, Water-supply development and management alternatives for Clinton, Eaton, and Ingham Counties, Michigan: U.S. Geological Survey Water-Supply Paper 1969, 111 p.

Westjohn, D.B., and Weaver, T.L., 1996, Hydrogeologic framework of Pennsylvanian and Late Mississippian rocks in the central Lower Peninsula of Michigan: U.S. Geological Survey Water-Resources Investigations Report 94-4107, $44 \mathrm{p}$.

Westjohn, D.B., Weaver, T.L., and Zacharias, K.F., 1994, Hydrogeology of Pleistocene glacial deposits and Jurassic "red beds" in the central Lower Peninsula of Michigan: U.S. Geological Survey Water-Resources Investigations Report 93-4152, 14 p. 




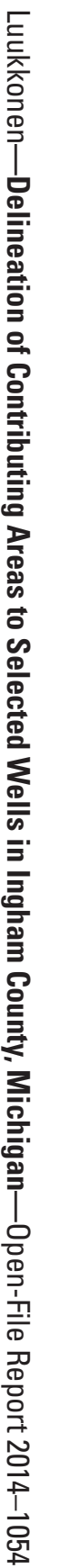

